\title{
Age-related susceptibility and resistance to nonlethal Plasmodium yoelii infection in C57BL/6 mice
}

\author{
Ying Shan $^{1,2}$, Jun Liu ${ }^{1}$, Yong-Jun Jiang ${ }^{3,4}$, Hong Shang ${ }^{3,4}$, Dong Jiang ${ }^{5}$ and Ya-Ming Cao ${ }^{1}$ \\ ${ }^{1}$ Department of Immunology, College of Basic Medical Sciences, China Medical University, No. 92 Beier Road, Heping District, \\ Shenyang 110001, China; \\ ${ }^{2}$ Department of Immunology and Pathogenic Biology, College of Basic Medical Sciences, Liaoning Medical University, Jinzhou \\ 121000, China; \\ ${ }^{3}$ Department of Laboratory Medicine, First Hospital of China Medical University, Shenyang 110001, China; \\ ${ }^{4}$ The Key Laboratory of AIDS Immunology of Ministry of Health, First Hospital of China Medical University, Shenyang 110001, \\ China; \\ ${ }^{5}$ Department of Anatomy, College of Basic Medical Sciences, Liaoning Medical University, Jinzhou 121000, China
}

\begin{abstract}
In cases of human malaria, children suffer very high rates of morbidity and mortality. To analyse the mechanisms involved in age-dependent protection against malaria, we investigated the characterization of immune responses to Plasmodium yoelii 17XNL (P.y 17XNL) in young (3 weeks) and middle-aged (8 months) C57BL/6 mice. In this study, we found that 100\% of young mice succumbed to P.y $17 \mathrm{XNL}$ infection with higher parasitemia, while middle-aged mice were able to clear blood parasites and no mortality was observed. These observations suggested that the young C57BL/6 mice were susceptible to P.y 17XNL infection, whereas the middle-aged mice were resistant. Cellular analysis revealed that both the numbers of splenic myeloid dendritic cells (mDCs) as well as the expression of DC maturation markers were higher in middle-aged mice than those in young mice. The numbers of IgG1- or IgG2asecreting B cells increased markedly in middle-aged mice after infection with P.y 17XNL. The dynamic change of the number of $\mathrm{CD}^{+} \mathrm{CD} 25^{+} \mathrm{Foxp}^{+}$regulatory T cells (Tregs) in mice infected with P.y $17 \mathrm{XNL}$ was also different between the two groups. In addition, the levels of IFN- $\gamma$ and NO increased in both groups during early parasite infection, while there was also an obvious increase in IL-4 production in the infected middle-aged mice. The change in IL-10 levels following infection was consistent with that of the change in the number of Tregs. The survival of middle-aged mice following P.y 17XNL infection was dependent upon the establishment of effective Th1 and Th2 responses and a successful switch between Th1 and Th2 responses, as well as appropriate functioning of Tregs.
\end{abstract}

Keywords: Plasmodium yoelii 17XNL, age, immune response, dendritic cells, Tregs

Malaria, caused by parasites of the genus Plasmodium Marchiafava et Celli, 1885, remains one of the leading causes of morbidity and mortality in the world, with a conservative estimate of 350-500 million individuals currently infected and causing in excess of one million deaths per year, mainly in children (Moormann 2009, Pierce and Miller 2009). Moreover, the findings of malaria mortality for the period 1980-2010 showed that the malaria mortality burden is larger than previously estimated (Murray et al. 2012). Events leading to the manifestations of severe malaria in a pediatric population are influenced by multiple intrinsic as well as extrinsic factors. These include, but are not limited to, intensity of malaria transmission, genetic diversity of the infecting parasite and complexity of infection, degree of maternal antibody protection and prenatal malaria experience, fetal hemoglob- in, hemoglobin S heterozygosity and nutritional status (Moormann 2009). These factors aside, children remain more susceptible to malaria in comparison to adults. This age-associated susceptibility has in part been explained by the fact that children can be immunologically naïve, and repeated infections are required to develop a repertoire of immune cells capable of recognizing the various and antigenic variant malaria-derived proteins. Once infected, however, children are more likely to succumb to the immunopathology associated with malaria (Maitland and Marsh 2004), which is primarily the result of insufficient modulation of TNF- $\alpha$ mediated pro-inflammatory responses induced by parasite molecules and antigens that stimulate innate and adaptive immunity (Clark and Schofield 2000, Artavanis-Tsakonas et al. 2003). According to human immunoepidemiological studies, it appears

Address for correspondence: Y.-M. Cao, Department of Immunology, College of Basic Medical Sciences, China Medical University, No. 92 Beier Road, Heping District, Shenyang, China. Phone: +86 2423256666 5346; Fax: +86 24 23264417; E-mail: ymcao@mail.cmu.edu.cn 
that the underlying pathophysiological determinants in children are still poorly known. Adults living in endemic areas can acquire protection against chronic exposure (Baird 1998, Murphy and Breman 2001). To understand this age-related susceptibility and protection of humans from malaria infection, several studies have demonstrated that the immune response and manifestations to malaria in children and adults are different (Xainli et al. 2002, Perkmann et al. 2005, Ramharter et al. 2005, Vestergaard et al. 2008, Khosravi et al. 2011, Lacerda et al. 2012). Comparison of cell-mediated activity of circulating cytokine levels in children and adults in different areas of malaria transmission has shown predominantly Th1-like responses in children, and a tendency to Th2-like responses in adults (Troye-Blomberg et al. 1990, Mshana et al. 1991, Riley et al. 1991, 1992, Elghazali et al. 1995, Luty et al. 1999, Le Hesran et al. 2006). However, it is not clear which immune responses are lacking in infants and young children, yet confer the semi-immune status that benefits adults. Thus, further understanding of the age-dependent characteristics of protection and susceptibility to parasites that cause malaria is necessary for the development of urgently needed vaccines.

The most serious limitation of the progress of characterization of the age-dependent immunological mechanisms in malaria infection was the lack of suitable laboratory animal model. However, over the past several years, the use of resistant, susceptible and genetically deficient mice, together with different Plasmodium strains, has allowed the in-depth dissection of the immunological mechanisms in adult mice (Langhorne et al. 1989, 2002, Taylor-Robinson 1995, Li et al. 2001, Longley et al. 2011). From these studies, it is clear that both cellular and humoral immune responses are required to control and clear malaria parasites.

In one of the previous studies, it was suggested that the phenomenon of age-related susceptibility or resistance to malaria in mice has not been well established (Pierrot et al. 2003). However, that experiment was carried out using the lethal strain, P.b ANKA in mice aged 4, 10 and 16 weeks. Interestingly, it was suggested almost 60 years ago that aged mice (12 months) infected with P.b ANKA survived longer than adult mice (12 weeks) (Greenberg et al. 1953).

In the present study, in order to better understand ageassociated differences in immunity to malaria, we used a C57BL/6 mouse model to define differences in cellular, humoral and cytokine responses between young (3 weeks) and middle-aged ( 8 months) mice infected with P.y 17XNL (nonlethal strain), which was described by Landau et al. (1968). We also used this model to investigate whether any of these responses may provide protection against infection in young mice. This mouse model may also be useful to study the phenomenon of age-related susceptibility or resistance to malaria in humans.

\section{MATERIALS AND METHODS}

\section{Mice, parasites and experimental infection}

Three week old (young) and 8 month old (middle-aged) female C57BL/6 mice were purchased from Beijing Animal Institute (Beijing, China). P.y $17 \mathrm{XNL}$ was kindly provided by Dr. Motomi Torii (Department of Molecular Parasitology, Ehime University Graduate School of Medicine, Ehime, Japan). Infections were initiated by intraperitoneal (i.p.) injection of $1 \times 10^{6}$ P.y $17 \mathrm{XNL}$ parasitized erythrocytes per mouse in each group of young and middle-aged C57BL/6 mice. Parasitemia was monitored by counting the number of parasite-infected erythrocytes per 1000 erythrocytes by light microscopic examination of Giemsa-stained thin smears of tail blood. All experiments were performed in compliance with local Animal Ethics Committee requirements.

\section{Spleen cell cultures}

Splenocyte culture was performed as previously described (Chen et al. 2009). Briefly, spleens from normal and infected mice were removed aseptically and pressed through a sterile fine wire mesh with $10 \mathrm{ml}$ RPMI 1640 supplemented with $10 \%$ heat-inactivated fetal calf serum (FCS), $25 \mathrm{mM}$ HEPES, $0.12 \%$ gentamicin and $2 \mathrm{mM}$ glutamine. Cell suspensions were collected by centrifuging at $350 \mathrm{~g}$ for $10 \mathrm{~min}$. Erythrocytes were lysed with cold $0.17 \mathrm{M} \mathrm{NH}_{4} \mathrm{Cl}$ and cells were washed twice with fresh medium. The viability of cells was determined by trypan blue exclusion and was always $>90 \%$. Aliquots $(500 \mu \mathrm{l} /$ well $)$ of the cell suspensions $\left(1 \times 10^{7} / \mathrm{ml}\right)$ were incubated in 24 -well flat bottom tissue culture plates (Falcon) in triplicate for $48 \mathrm{~h}$ at $37^{\circ} \mathrm{C}$ in a humidified $5 \% \mathrm{CO}_{2}$ incubator. Supernatant fractions were collected and stored at $-80^{\circ} \mathrm{C}$ until they were assayed ( $\mathrm{Su}$ and Stevenson 2002).

\section{Flow cytometry analysis}

A portion of the infected mice were sacrificed simultaneously at the indicated times, in order to measure $\mathrm{mDCs}$, the popula-

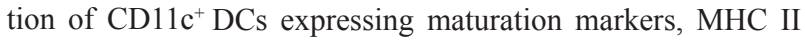
and CD86, Tregs, and IgG1- and IgG2a-secreting B cells. Unless otherwise indicated, antibodies were purchased from BD Biosciences.

Spleen cells from C57BL/6 mice were collected at different time points after infection. To assess DCs, cells were double stained with FITC-conjugated anti-CD11c mAb (clone HL-3) and PE-conjugated anti-CD11b (clone M1/70), anti-CD86 mAb (clone 3/23), and anti-MHC II mAb (clone M5/114.15.2) (Grelli et al. 2004). To assess Tregs, FITC-conjugated anti-CD4 and PE-conjugated anti-CD25 antibodies (clone PC61) were added to spleen cells, and the cells were then resuspended in $100 \mu \mathrm{l}$ of phosphate-buffered saline supplemented with 3\% FCS for surface staining. The cells were then fixed and permeabilized, and intracytoplasmic staining was performed using APC-conjugated anti-Foxp3 antibody (clone FJK16s) (Seixas and Ostler 2005). To measure IgG1- and IgG2a-secreting B cells, the cells were first surfaced-stained with PerCP-conjugated anti-CD45R/B220 (clone RA3-6B2). Cells were then fixed, permeabilized and stained with anti-IgG1 or anti-IgG2a. 
The cells were then washed twice with PBS containing $1 \%$ FCS and suspended in $300 \mu \mathrm{l}$ of PBS, and analyzed in FACSCalibur cytofluorometer using CellQuest software. Viable cells were gated by forward and side scattering.

\section{Detection of cytokines by ELISA}

Levels of IFN- $\gamma$, IL- 4 and IL-10 were measured by commercial enzyme linked immunosorbent assay (ELISA) kits according to the manufacturer's protocol (R\&D Systems, Minneapolis, $M N)$. The OD values were read in a microplate reader at $450 \mathrm{~nm}$. The concentration of cytokines in each sample was calculated using a standard curve generated using recombinant cytokines.

\section{Determination of nitrite $\left(\mathrm{NO}_{2}^{-}\right)$concentration}

To determine NO production, concentrations of $\mathrm{NO}_{2}^{-}$in cell supernatants were measured by the Griess reaction (Yanez et al. 1996). Briefly, $100 \mu \mathrm{l}$ of supernatant was incubated with $100 \mu \mathrm{l}$ of Griess reagent for $10 \mathrm{~min}$ at room temperature, and $\mathrm{NO}_{2}^{-}$ concentration was determined by measuring the optical density at $550 \mathrm{~nm}$ (A550) in reference to the $\mathrm{A} 550$ of standard $\mathrm{NaNO}_{2}$ solution.

\section{Statistical analysis}

Data are presented as the means \pm standard errors of the means (SE). Statistical significance of the differences was analyzed by $t$ test or one way ANOVA (SPSS 17.0). A value of $\mathrm{p}<0.05$ was considered significant.

\section{RESULTS}

\section{Infection course and levels of IFN- $\boldsymbol{\gamma}$ and NO}

In the present study, young and middle-aged C57BL/6 mice were infected with P.y 17XNL and showed divergent courses of infection and disease severity. Infection with P.y $17 \mathrm{XNL}$ was lethal on day 20 to the young mice with peak parasitemia of about $42 \%$. By contrast, middle-aged mice survived infection with P.y $17 \mathrm{XNL}$ and developed a moderate parasitemia, which increased steadily from approximately $2 \%$ on day 4 post-infection (pi) to $20 \%$ on day 12 pi and dropped thereafter (Fig. 1A). These observations indicated that the young C57BL/6 mice were susceptible to P.y $17 \mathrm{XNL}$ infection, whereas the middle-aged mice were relatively resistant.

Our previous studies have demonstrated that resistance to blood stage malaria infections depended on the ability to induce an early effective Th1 cellar immune response. Therefore, we investigated the level of the Th1 cytokine, IFN- $\gamma$ in mice following infection with P.y $17 \mathrm{XNL}$. Increased IFN- $\gamma$ production was observed on day 5 pi in both young and middle-aged mice (Fig. 1B). Similar patterns of NO production were observed in each group during the early stage of infection. As shown in Fig. 1C, NO levels in the culture supernatant of splenocytes from each group peaked on day 5 pi.
A

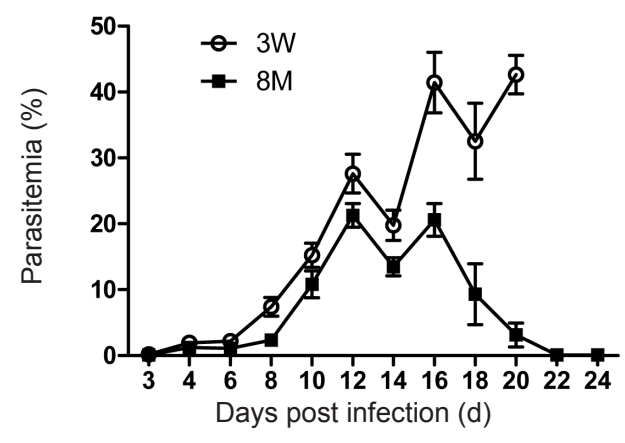

B

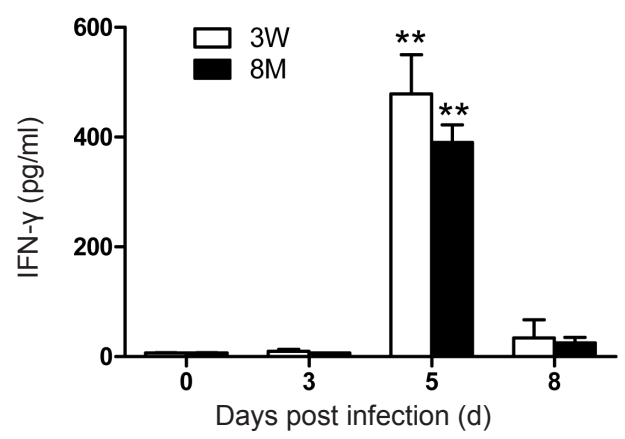

C

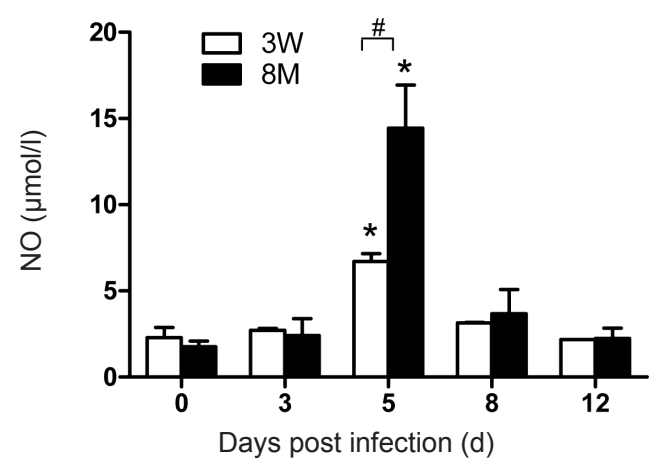

Fig. 1. Parasitemia and levels of IFN- $\gamma$ and NO in young (3W) and middle-aged $(8 \mathrm{M})$ mice infected with P.y $17 \mathrm{XNL}$. Percentages of parasitemia were calculated by counting the number of parasite-infected erythrocytes per 1000 total erythrocytes by light microscopic examination of Giemsa-stained thin smears of tail blood. ELISA was performed to detect levels of IFN- $\gamma$ in supernatants of cultured spleen cells from infected mice. The concentration of $\mathrm{NO}_{2}^{-}$was detected using the Griess reaction. Results were presented as the arithmetic mean of three mice per group \pm SE. $* \mathrm{p}<0.05, * * \mathrm{p}<0.01$ versus corresponding values for non-infected control mice $(0 \mathrm{~d})$; \# $\mathrm{p}<0.05$ indicates the comparison between young and middle-aged mice. 


\section{Number of mDCs and DC maturation markers}

Dendritic cells (DCs) are the sole antigen presenting cells (APC) responsible for initiating naïve T lymphocyte activation. Therefore, we examined the myeloid dendritic cells (mDCs) in mice of different ages. We also compared the expression of the DC maturation markers MHC II and CD86 on splenic CD11 ${ }^{+}$DCs, which are essential for induction of a $\mathrm{T}$ cell response. The results revealed that the numbers of mDCs (Fig. 2A), and the expression of $\mathrm{MHC}$ II (Fig. 2B) and CD86 (Fig. 2C) increased after infection in each group with a peak on day 8 pi. The peak values were significantly different from those of uninfected mice.

A

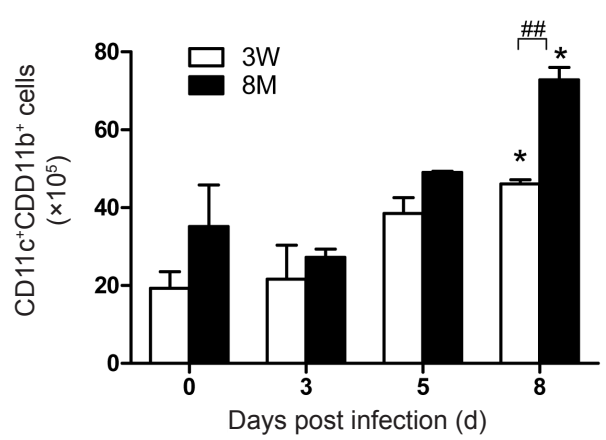

B

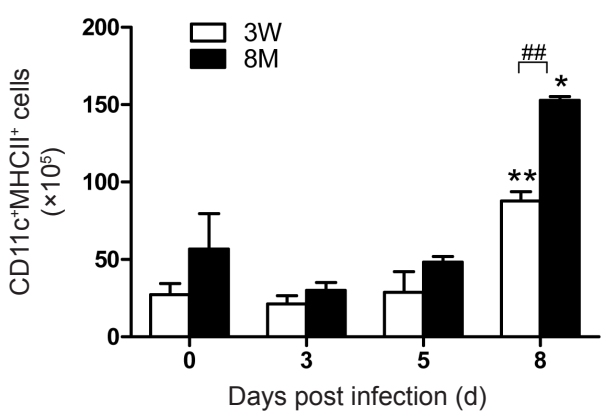

C

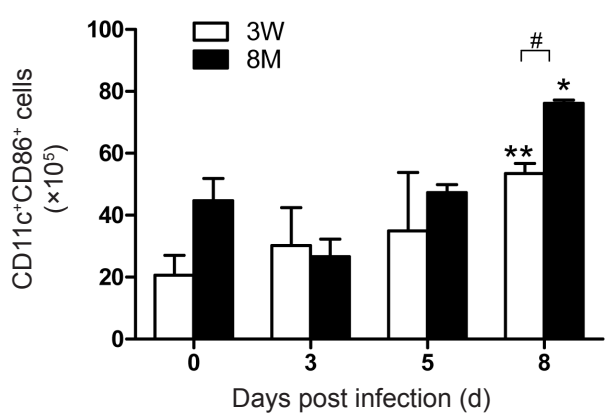

Fig. 2. The maturation and activation of dendritic cells (DCs) in the spleen of young $(3 \mathrm{~W})$ and middle-aged $(8 \mathrm{M})$ mice during P.y $17 \mathrm{XNL}$ infection. Flow cytometry was used to detected numbers of myeloid dendritic cells (mDCs), CD11 ${ }^{+} \mathrm{MHCII}^{+} \mathrm{DCs}$, and $\mathrm{CD} 11 \mathrm{c}^{+} \mathrm{CD} 86^{+} \mathrm{DCs}$ at different time points after infection. Results were presented as the arithmetic mean of three mice per group \pm SE. $* \mathrm{p}<0.05, * * \mathrm{p}<0.01$ versus corresponding values for non-infected control mice $(0 \mathrm{~d})$; $\# \mathrm{p}<0.05$, \#\# $\mathrm{p}<0.01$ indicates the comparison between young and middle-aged mice.
Importantly, both the numbers of DCs and the expression of DC maturation markers were significantly lower in young mice than those in middle-aged mice at peak.

\section{$\mathrm{IgG1}^{+}$or $\mathrm{IgG} \mathrm{a}^{+} \mathrm{B}$ cells and IL-4 level}

To investigate whether splenic B cells exhibit changes in accordance with the observed age-associated susceptibility and resistance to P.y $17 \mathrm{XNL}$, the numbers of IgG1- or IgG2a-secreting B cells were analysed by flow cytometry. The results revealed that the numbers of B cells secreting IgG1 (Fig. 3A) or IgG2a (Fig. 3B) increased obviously in middle-aged mice after infection
A

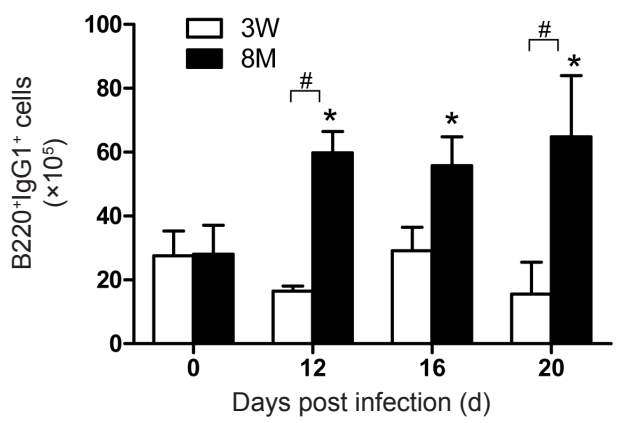

B

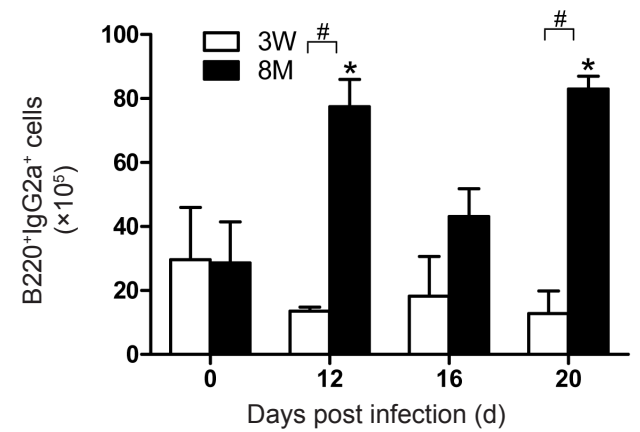

C

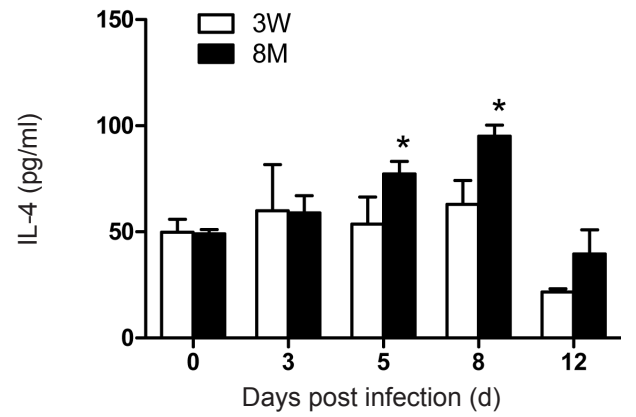

Fig. 3. Secretion of $\operatorname{IgG} 1$ or $\operatorname{IgG} 2 \mathrm{a}$ by spleen B cells and level of IL-4 in young (3W) and middle-aged (8M) mice during P.y $17 \mathrm{XNL}$ infection. Flow cytometry was used to detect numbers of $\mathrm{CD} 45 \mathrm{R} / \mathrm{B} 220^{+} \mathrm{IgG} 1^{+} \mathrm{B}$ cells and $\mathrm{CD} 45 \mathrm{R} / \mathrm{B} 220^{+} \mathrm{IgG} 2 \mathrm{a}^{+} \mathrm{B}$ cells on day 12,16 and 20 after infection. ELISA was performed to detect levels of IL-4 in supernatants of cultured spleen cells from infected mice. Results were obtained from three individual mice at each time point. $* \mathrm{p}<0.05$ versus corresponding values for non-infected control mice $(0 \mathrm{~d}) ; \# \mathrm{p}<0.05$ indicates the comparison between young and middle-aged mice. 
with P.y 17XNL, whereas there was no obvious change in the numbers of these B cells in young mice compared to corresponding values for non-infected mice. These results showed that B cells in the middle-aged mice are able to be activated and secrete large amounts of IgG1 and IgG2a when these mice were infected with P.y 17XNL.

The activation and secretion of IgG1 or IgG2a by B cells depend on Th2 cytokines, such as IL-4. Therefore, we evaluated the levels of IL-4 in supernatants from cultured spleen cells of infected mice. In middle-aged mice, on day 5 and 8 pi, there was an obvious increase in IL-4 production, which implied a switch in the immune response from Th1 to Th2. There was no obvious change in the levels of IL-4 in young mice compared to the corresponding values for non-infected mice (Fig. 3C).

\section{Tregs cell number and IL-10 level}

To compare the immunoregulatory effects of Tregs in mice of different ages during malaria parasite infection, flow cytometric analysis was performed. Tregs in splenocytes were evaluated by triple staining with FITCanti-CD4, PE-anti-CD25 and APC-anti-Foxp3 monoclonal antibodies, in both young and middle-aged mice infected with P.y 17XNL. The number of Tregs increased and peaked (absolute cell number, $8.369 \times 10^{6}$ ) on day 3 pi and then decreased in young mice. In adult mice, the number of Tregs increased on day 3 pi and reached a peak (absolute cell number, $1.69 \times 10^{7}$ ) on day 8 pi (Fig. 4A). Importantly, the number of Tregs in middle-aged mice on day 8 pi was much higher than that in young mice.

To demonstrate the potential mechanisms of immunosuppression by Tregs, we evaluated the levels of the Th1 inhibitory cytokine IL-10 in splenocyte culture supernatants from mice infected with malaria parasite. An increase in IL-10 production was found after infection in both groups. The level of IL-10 peaked on day 5 pi in young mice and on day 8 pi in middle-aged mice (Fig. 4B), which was consistent with the change in numbers of Tregs. These results suggested that Tregs had an important role in regulation associated with the induction of IL-10.

\section{DISCUSSION}

In adults, exposure over several years appears to be necessary for the acquisition of resistance to many parasite variants and for mounting effective immune responses. However, many studies have shown that adults acquire resistance more rapidly than children (Baird et al. 1991, 1993, Baird 1995). To understand this age-related susceptibility and protection of humans to malaria infection, several epidemiology studies have addressed the issue of whether the immune response to malaria in children and adults is different. There may be several mechanisms potentially involved in immune hyporesponsiveness in young mice and humans, such as developmental immaturity of APCs thus influencing establishment of effec-
A

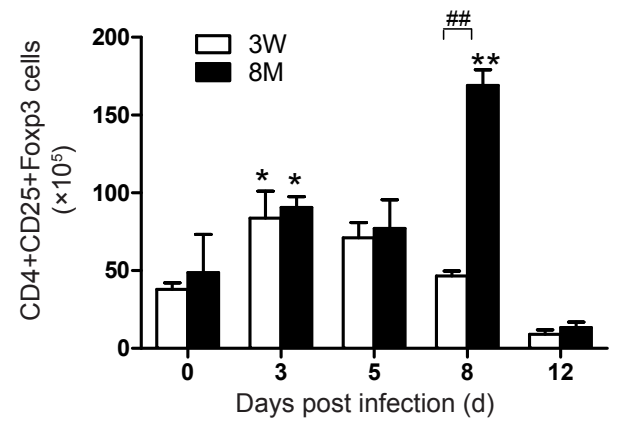

B

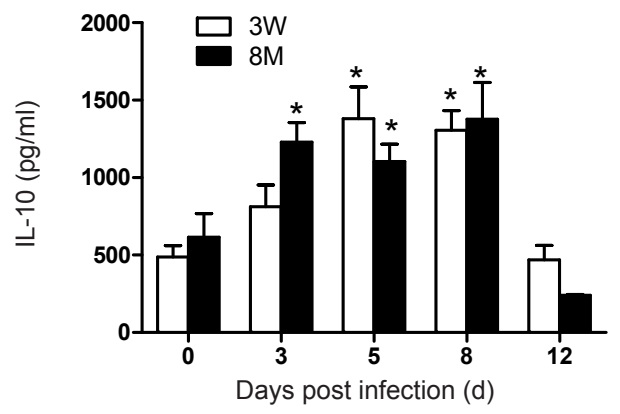

Fig. 4. Number of Tregs and level of IL-10 in young (3W) and middle-aged (8M) mice during P.y 17XNL infection. The numbers of $\mathrm{CD}^{+} \mathrm{CD} 25^{+} \mathrm{Foxp}^{+}$Tregs in total spleen $\mathrm{T}$ cell populations were measured by flow cytometry in C57BL/6 mice after infection with P.y 17XNL. ELISA was performed to detect the levels of IL-10 in supernatants of cultured spleen cells from infected mice. Results were presented as the arithmetic mean of three mice per group \pm SE. $* \mathrm{p}<0.05, * * \mathrm{p}<0.01$ versus corresponding values for non-infected control mice $(0 \mathrm{~d}) ; \#$; $<0.01$ indicates the comparison between young and middle-aged mice.

tive T cell-APC interactions (Hunt et al. 1994, MarshallClarke et al. 2000), incomplete signalling because of low expression of CD40L on T cells (Brugnoni et al. 1994), and/or impaired responsiveness to TLR ligands leading to a lack of appropriate cytokine production (Levy et al. 2004). In experimental malaria, the most extensive work on immune responses has been conducted using adult mouse models with no clear studies on the effects of age. From these studies, it appears that cellular and humoral responses are essential actors in the control and clearance of malaria parasites (Taylor-Robinson 1995, Li et al. 2001, Langhorne et al. 2002). In order to more carefully consider the impact of age on the biology of host-parasite interactions in malaria, we attempted to identify differential changes in the immune response that may occur during infection in young and middle-aged C57BL/6 mice infected with P.y 17XNL.

In this study, we found that the course of infection was significantly affected by age, as infection with P.y $17 \mathrm{XNL}$ resulted in contradictory outcomes in young and middleaged mice. We showed that young mice (3 weeks) succumbed to P.y $17 \mathrm{XNL}$ infection, while middle-aged mice (8 months) cleared the parasites and survived the infec- 
tion, which indicated that the combination of C57BL/6 mice and P.y 17XNL infection may be considered a valuable model for studying the age-related changes of the immune responses during infection.

We previously demonstrated that the uncontrolled proliferation of blood stage malaria parasites was the main cause of death in mice infected with Plasmodium. $\mathrm{CD}^{+} \mathrm{Th} 1$ immune effectors were found to be crucial in controlling the proliferation of parasites during early infection by triggering cellular immune responses (Urban et al. 2005). However, T lymphocyte activation and differentiation depend upon DCs, which provide a critical role in initiating adaptive immune responses (Banchereau and Steinman 1998). The splenic DC compartment is a heterogeneous population with subsets of cells differing in functions and morphologies (Shortman and Liu 2002). Th1 responses are mainly mediated by mDCs (Liu 2001, Kuwana 2002, Jangpatarapongsa et al. 2008) and thus we compared the numbers of $\mathrm{mDC}$ and DC maturation as measured by the expression of DCs maturation markers, MHC II and CD86, which are essential for induction of T cell responses (Sher et al. 2003, Cervi et al. 2004).

These results showed that both the number of $\mathrm{mDCs}$ and the expression of MHC II and CD86 increased significantly after infection on day 8 pi in both young and middle-aged mice, indicating that infection with P.y 17XNL could induce the maturation and activation of DCs in both young and middle-aged C57BL/6 mice. The proliferation and activation of DCs allows for the Th1 response to control the proliferation of parasites in early infection in both groups of mice, which was consistent with the previous studies that $\mathrm{CD}^{+} \mathrm{T}$ cells were associated with protection against malaria through the control of growth of blood parasite stages (Meding and Langhorne 1991, Weiss et al. 1993, Phillips et al. 1994).

We also evaluated Th1-type immune responses as measured by the production of IFN- $\gamma$ and NO. The level of IFN- $\gamma$ and NO increased markedly in each group following infection. These results demonstrated that successful resistance to blood stage malaria infections in mice depended on their ability to induce an early effective Th1 cellular immune response characterized by predominant IFN- $\gamma$ secretion, which might promote NO production to control parasite growth as previously described (Jacobs et al. 1995, 1996). The significant difference in NO release between the young and middle-aged mice on day 5 pi could explain that the parasitemia level of middleaged mice was lower than that of young mice during early infection. Therefore, both young and middle-aged mice infected with P.y 17XNL were able to mount effective pro-inflammatory Th1 responses.

IFN- $\gamma$ production was used as a measure of Th1 responsiveness and IL-4 production was used as a measure of Th2 responsiveness (Achidi et al. 2005). In addition, related studies have shown that effective establishment of a Th1 immune response and a successful switch to a Th2 response are crucial for protective immunity against malaria. Balanced and coordinated Th1/Th2 regulation not only controls the crisis of the acute phase, but also facilitates the ultimate elimination of the malaria-causing parasite (Taylor-Robinson et al. 1993, Malhotra et al. 2005). In this study, we found that there was a successful switch to the Th2 response in the middle-aged mice infected with P.y 17XNL. This Th2 response was characterized by a high level of IL-4, and was also supported by the increased numbers of IgG1- or IgG2a-secreting B cells. Secretion of IgG1 and IgG2a antibodies have been shown to be controlled by Th2 cytokines (Binder et al. 1995). It has been demonstrated that specific antibodies are responsible for the clearance of the parasites that cause malaria thereafter (Taylor-Robinson and Phillips 1994, Couper et al. 2005, Yazdani et al. 2006, Moneriz et al. 2011, Clark et al. 2012).

In the current experiments, we demonstrated that Th2 cytokines such as IL-4 promoted B cells to secrete IgG1 and $\operatorname{IgG} 2 \mathrm{a}$, which played a crucial role in the final clearing of parasites from the blood leading to survival of the middle-aged mice after P.y 17XNL infection. In the group of young mice, a pro-inflammatory Th1 response was successfully established, but did not successfully switch to an anti-inflammatory Th2 response, thus not producing the specific antibodies that were necessary to clear the parasites.

Immunity against severe malaria may also depend upon the host's ability to fine tune the magnitude and process of the cellular immune response, which allows appropriate production and timing of inflammatory or anti-inflammatory cytokines at key stages of the infection. A proper balance between pro- and anti-inflammatory immune responses is essential to control the pathogenesis of severe malaria (Walther et al. 2009, Cox-Singh et al. 2011) in which Tregs might serve as an important regulator (Wu et al. 2010, Berretta et al. 2011, Lyke et al. 2012). The suppression of Tregs in malaria infection has been addressed in a rodent model by presenting an increased survival associated with higher T-cell responsiveness against parasite-derived antigens after depletion of Tregs (Hisaeda et al. 2004). Tregs can exert their function in an IL-10 dependent manner (Belkaid et al. 2002, Okamoto et al. 2011). One human study reported a close relationship between increased percentages of Tregs and elevated IL10 responses to antigen of $P$. falciparum (Welch, 1897) in cord blood mononuclear cells (Brustoski et al. 2006).

In the present study, we showed that the activation of Tregs was accompanied by high levels of IL-10, which was also consistent with our previous studies (Wu et al. 2007, Chen et al. 2009). Here, the number of Tregs peaked on day 8 pi in middle-aged mice infected with P.y 17XNL, while in young mice, the number of Tregs peaked on day 3 pi. Moreover, the number of Tregs in middle-aged mice 
on day 8 pi was about three-fold higher than in young mice on the same day. Thus, these data showed a marked difference in kinetics of the proliferation of Tregs and the production of the immunoregulatory cytokine IL-10 between the young susceptible and middle-aged resistant mice infected with P.y 17XNL. Considering the expansion of Tregs in the middle-aged resistant mice infected with P.y $17 \mathrm{XNL}$ at the later time point (day 8 pi), we speculated that this proliferation might limit the excessive Th1 reaction and then switch to a Th2 response, resulting in increased antibody production to abrogate the parasites. This speculation is based on the crucial roles of Tregs in regulating Th1/Th2 responses and in the shift of Th1 to Th2 cells (Artavanis-Tsakonas and Riley 2002, Song et al. 2009). In the young susceptible mice, the failure of activation of Tregs at the critical phase for establishing an effective Th2 response (day 8 pi) would lead to an ineffective Th2 response, resulting in the death of these mice. The possible mechanisms remain to be clarified. The previous study also proved that inappropriate functioning of Tregs resulted in the death in young susceptible rats (Adam et al. 2003).
Taken together, the young C57BL/6 mice were susceptible, whereas the middle-aged mice were resistant to P.y 17XNL infection, which implies that C57BL/6 mice infected with P.y 17XNL may be considered as a model for studying the age-related changes of the immune responses during infection. The middle-aged mice survived after P.y 17XNL infection, and survival was dependent on the establishment of effective Th1 and Th2 responses, a successful switch between Th1 and Th2 responses, and appropriate functioning of Tregs. This study also indicated that we could use IL-4 or IL-10 agonist at appropriate time to promote a successful switch between Th1 and Th2 responses in rodent species during the plasmodium infection.

Acknowledgements. We thank Dr. Motomi Torii (Ehime University Graduate School of Medicine, Ehime, Japan) for providing malaria parasite strains of P.y 17XNL. We are also grateful to the Department of Immunology, China Medical University, Shenyang for technical help and logistical support during this study.

\section{REFERENCES}

Achidi E.A., Anchang J.K., Minang J.T., Ahmadou M.J., Troye-Blomberg M. 2005: Studies on Plasmodium falciparum isotypic antibodies and numbers of IL-4 and IFN-gamma secreting cells in paired maternal cord blood from South West Cameroon. Int. J. Infect. Dis. 9: 159-169.

Adam E., Pierrot C., Lafitte S., Godin C., Saoudi A., Capron M., Khalife J. 2003: The age-related resistance of rats to Plasmodium berghei infection is associated with differential cellular and humoral immune responses. Int. J. Parasitol. 33: 1067-1078.

Artavanis-Tsakonas K., Riley E.M. 2002: Innate immune response to malaria: rapid induction of IFN-gamma from human NK cells by live Plasmodium falciparum-infected erythrocytes. J. Immunol. 169: 2956-2963.

Artavanis-Tsakonas K., Tongren J.E., Riley E.M. 2003: The war between the malaria parasite and the immune system: immunity, immunoregulation and immunopathology. Clin. Exp. Immunol. 133: 145-152.

BAIRD J.K. 1995: Host age as a determinant of naturally acquired immunity to Plasmodium falciparum. Parasitol. Today 11: 105-111.

BAIRD J.K. 1998: Age-dependent characteristics of protection v. susceptibility to Plasmodium falciparum. Ann. Trop. Med. Parasitol. 92: 367-390.

Baird J.K., Jones T.R., Danudirgo E.W., Annis B.A., Bangs M.J., BAsri P.H., Masbar S. 1991: Age-dependent acquired protection against Plasmodium falciparum in people having two years exposure to hyperendemic malaria. Am. J. Trop. Med. Hyg. 45: 65-76.

Baird J.K., Basri P.H., Bangs M.J., Andersen E.M., Jones T.R., Masbar S., Harjosuwarno S., Subianto B., Arbani P.R. 1993: Age-specific prevalence of Plasmodium falciparum among six populations with limited histories of exposure to endemic malaria. Am. J. Trop. Med. Hyg. 49: 707-719.

Banchereau J., Steinman R.M. 1998: Dendritic cells and the control of immunity. Nature 392: 245-252.

Belkaid Y., Piccirillo C.A., Mendez S., Shevach E.M., Sacks D.L. 2002: CD4+CD25+ regulatory T cells control Leishmania major persistence and immunity. Nature 420: 502-507.

Berretta F., St-Pierre J., Piccirillo C.A., Stevenson M.M. 2011: IL-2 contributes to maintaining a balance between CD4+Foxp3+ regulatory $\mathrm{T}$ cells and effector CD4+ $\mathrm{T}$ cells required for immune control of blood-stage malaria infection. J. Immunol. 186: 4862-4871.

Binder J., Graser E., Hancock W.W., Wasowska B., Sayegh M.H., Volk H.D., Kupiec-Weglinski J.W. 1995: Downregulation of intragraft IFN-gamma expression correlates with increased IgG1 alloantibody response following intrathymic immunomodulation of sensitized rat recipients. Transplantation 60: 1516-1524.

Brugnoni D., Airo P., Graf D., Marconi M., Lebowitz M., Plebani A., Giliani S., Malacarne F., Cattaneo R., Ugaziou A.G., Albertiniu A., Kroczeku R.A., Notarangelo L.D. 1994: Ineffective expression of CD40 ligand on cord blood $\mathrm{T}$ cells may contribute to poor immunoglobulin production in the newborn. Eur. J. Immunol. 24: 1919-1924.

Brustoski K., Moller U., Kramer M., Hartgers F.C., KremSNer P.G., KRZYCh U., Luty A.J. 2006: Reduced cord blood immune effector-cell responsiveness mediated by CD4+ cells induced in utero as a consequence of placental Plasmodium falciparum infection. J. Infect. Dis. 193: 146-154.

Cervi L., MacDonald A.S., Kane C., Dzierszinski F., Pearce E.J. 2004: Cutting edge: dendritic cells copulsed with microbial and helminth antigens undergo modified maturation, seg- 
regate the antigens to distinct intracellular compartments, and concurrently induce microbe-specific Th1 and helminth-specific Th2 responses. J. Immunol. 172: 2016-2020.

Chen G., Liu J., Wang Q.H., Wu Y., Feng H., Zheng W., Guo S.Y., Li D.M., Wang J.C., CAO Y.M. 2009: Effects of CD4(+) CD25(+)Foxp3(+)regulatory T cells on early Plasmodium yoelii 17XL infection in BALB/c mice. Parasitology 136: 1107-1120.

Clark E.H., Silva C.J., Weiss G.H., Li S., Padilla C., Crompton P.D., Hernandez J.N., Branch O.H. 2012: Plasmodium falciparum malaria in the low transmission Peruvian Amazon is associated with immunologic memory. Infect. Immun. 80: 1583-1592.

Clark I.A., Schofield L. 2000: Pathogenesis of malaria. Parasitol. Today 16: 451-454.

Couper K.N., Phillips R.S., Brombacher F., Alexander J. 2005: Parasite-specific IgM plays a significant role in the protective immune response to asexual erythrocytic stage Plasmodium chabaudi AS infection. Parasite Immunol. 27: 171-180.

Cox-Singh J., Singh B., Daneshvar C., Planche T., ParkerWilliams J., Krishna S. 2011: Anti-inflammatory cytokines predominate in acute human Plasmodium knowlesi infections. PLoS ONE 6: e20541.

Elghazali G., Esposito F., Troye-Blomberg M. 1995: Comparison of the number of IL-4 and IFN-gamma secreting cells in response to the malaria vaccine candidate antigen Pf155/RESA in two groups of naturally primed individuals living in a malaria endemic area in Burkina Faso. Scand. J. Immunol. 42: 39-45.

Greenberg J., Nadel E.M., Coatney G.R. 1953: The influence of strain, sex and age of mice on infection with Plasmodium berghei. J. Infect. Dis. 93: 96-100.

Grelli S., D’Ettorre G., Lauria F., Montella F., Di Traglia L., Lichtner M., Vullo V., Favalli C., Vella S., Macchi B., Mastino A. 2004: Inverse correlation between CD8+ lymphocyte apoptosis and CD4+ cell counts during potent antiretroviral therapy in HIV patients. J. Antimicrob. Chemother. 53: 494-500.

Hisaeda H., Maekawa Y., Iwakawa D., Okada H., Himeno K., Kishinara K., Tsukumo S., Yasutomo K. 2004: Escape of malaria parasites from host immunity requires CD4+ CD25+ regulatory T cells. Nat. Med. 10: 29-30.

Hunt D.W., Huppertz H.I., Jiang H.J., Petty R.E. 1994: Studies of human cord blood dendritic cells: evidence for functional immaturity. Blood 84: 4333-4343.

Jacobs P., Radzioch D., Stevenson M.M. 1996: In vivo regulation of nitric oxide production by tumor necrosis factor alpha and gamma interferon, but not by interleukin-4, during blood stage malaria in mice. Infect. Immun. 64: 44-49.

Jacobs P., Radzioch D., Stevenson M.M. 1995: Nitric oxide expression in the spleen, but not in the liver, correlates with resistance to blood-stage malaria in mice. J. Immunol. 155: 5306-5313.

Jangpatarapongsa K., Chootong P., Sattabongkot J., Chotivanich K., Sirichaisinthop J., Tungpradabkul S., Hisaeda H., Troye-Blomberg M., Cui L., Udomsangpetch R. 2008: Plasmodium vivax parasites alter the balance of myeloid and plasmacytoid dendritic cells and the induction of regulatory T cells. Eur. J. Immunol. 38: 2697-2705.

Khosravi A., Hommel M., Sayemiri K. 2011: Age-dependent antibody response to Plasmodium falciparum merozoite surface protein 2 (MSP-2). Parasite Immunol. 33: 145-157.

KuWANA M. 2002: Induction of anergic and regulatory T cells by plasmacytoid dendritic cells and other dendritic cell subsets. Hum. Immunol. 63: 1156-1163.

Lacerda M.V., Mourao M.P., Alexandre M.A., Siqueira A.M., Magalhaes B.M., Martinez-Espinosa F.E., Santana
Filho F.S., Brasil P., Ventura A.M., Tada M.S., Couto V.S., Silva A.R., Silva R.S., Alecrim M.G. 2012: Understanding the clinical spectrum of complicated Plasmodium vivax malaria: a systematic review on the contributions of the Brazilian literature. Malaria J. 11: 12.

Landau I., Michel J.C., Adam J.P. 1968: Cycle biologique au laboratoire de Plasmodium berghei killicki n. sub. sp. Ann. Parasitol. Hum. Comp. 43: 545-549.

Langhorne J., Meding S.J., Eichmann K., Gillard S.S. 1989: The response of CD4+ $\mathrm{T}$ cells to Plasmodium chabaudi chabaudi. Immunol. Rev. 112: 71-94.

Langhorne J., Quin S.J., SAnni L.A. 2002: Mouse models of blood-stage malaria infections: immune responses and cytokines involved in protection and pathology. Chem. Immunol. 80: 204-228.

Le Hesran J.Y., Fievet N., Thioulouse J., Personne P., Maubert B., M’Bidias S., Etye’ale D., Cot M., Deloron P. 2006: Development of cellular immune responses to Plasmodium falciparum blood stage antigens from birth to 36 months of age in Cameroon. Acta. Trop. 98: 261-269.

Levy O., Zarember K.A., Roy R.M., Cywes C., Godowski P.J., Wessels M.R. 2004: Selective impairment of TLR-mediated innate immunity in human newborns: neonatal blood plasma reduces monocyte TNF-alpha induction by bacterial lipopeptides, lipopolysaccharide, and imiquimod, but preserves the response to R-848. J. Immunol. 173: 4627-4634.

Li C., Seixas E., Langhorne J. 2001: Rodent malarias: the mouse as a model for understanding immune responses and pathology induced by the erythrocytic stages of the parasite. Med. Microbiol. Immunol. 189: 115-126.

LIU Y.J. 2001: Dendritic cell subsets and lineages, and their functions in innate and adaptive immunity. Cell 106: 259-262.

Longley R., Smith C., Fortin A., Berghout J., McMorran B. Burgio G., Foote S., Gros P. 2011: Host resistance to malaria: using mouse models to explore the host response. Mamm. Genome 22: $32-42$.

Luty A.J., Lell B., Schmidt-Ott R., Lehman L.G., Luckner D., Greve B., Matousek P., Herbich K., Schmid D., MigotNabias F., Deloron P., Nussenzweig R.S., Kremsner P.G. 1999: Interferon-gamma responses are associated with resistance to reinfection with Plasmodium falciparum in young African children. J. Infect. Dis. 179: 980-988.

Lyke K.E., Dabo A., Arama C., Daou M., Diarra I., Wang A., Plowe C.V., Doumbo O.K., Sztein M.B. 2012: Reduced $\mathrm{T}$ regulatory cell response during acute Plasmodium falciparum infection in Malian children co-infected with Schistosoma haematobium. PLoS ONE 7: e31647.

Maitland K., Marsh K. 2004: Pathophysiology of severe malaria in children. Acta Trop. 90: 131-140.

Malhotra I., Mungai P., Muchiri E., Ouma J., Sharma S., KaZURA J.W., KInG C.L. 2005: Distinct Th1- and Th2-Type prenatal cytokine responses to Plasmodium falciparum erythrocyte invasion ligands. Infect. Immun. 73: 3462-3470.

Marshall-Clarke S., Tasker L., Parkhouse R.M. 2000: Immature B lymphocytes from adult bone marrow exhibit a selective defect in induced hyperexpression of major histocompatibility complex class II and fail to show B7.2 induction. Immunology 100: 141-151.

Meding S.J., Langhorne J. 1991: CD4+ T cells and B cells are necessary for the transfer of protective immunity to Plasmodium chabaudi chabaudi. Eur. J. Immunol. 21: 1433-1438.

Moneriz C., Marin-Garcia P., Bautista J.M., Diez A., Puyet A. 2011: Parasitostatic effect of maslinic acid. II. Survival increase and immune protection in lethal Plasmodium yoeliiinfected mice. Malaria J. 10: 103. 
Moormann A.M. 2009: How might infant and paediatric immune responses influence malaria vaccine efficacy? Parasite Immunol. 31: 547-559.

Mshana R.N., Boulandi J., Mshana N.M., Mayombo J., MenDOME G. 1991: Cytokines in the pathogenesis of malaria: levels of IL-I beta, IL-4, IL-6, TNF-alpha and IFN-gamma in plasma of healthy individuals and malaria patients in a holoendemic area. J. Clin. Lab. Immunol. 34: 131-139.

Murphy S.C., Breman J.G. 2001: Gaps in the childhood malaria burden in Africa: cerebral malaria, neurological sequelae, anemia, respiratory distress, hypoglycemia, and complications of pregnancy. Am. J. Trop. Med. Hyg. 64: 57-67.

Murray C.J., Rosenfeld L.C., Lim S.S., Andrews K.G., Foreman K.J., Haring D., Fullman N., Naghavi M., Lozano R., Lopez A.D. 2012: Global malaria mortality between 1980 and 2010: a systematic analysis. Lancet 379: 413-431.

Окамото A., Fujo K., Okamura T., Yamamoto K. 2011: Regulatory T-cell-associated cytokines in systemic lupus erythematosus. J. Biomed. Biotechnol. 2011: 463412.

Perkmann T., Winkler H., Graninger W., Kremsner P.G., WINKLER S. 2005: Circulating levels of the interleukin (IL)-4 receptor and of IL-18 in patients with Plasmodium falciparum malaria. Cytokine 29: 153-158.

Phillips R.S., Mathers K.E., Taylor-Robinson A.W. 1994: T cells in immunity to Plasmodium chabaudi chabaudi: operation and regulation of different pathways of protection. Res. Immunol. 145: 406-412.

Pierce S.K., Miller L.H. 2009: World Malaria Day 2009: what malaria knows about the immune system that immunologists still do not. J. Immunol. 182: 5171-5177.

Pierrot C., Adam E., Lafitte S., Godin C., Dive D., Capron M., Khalife J. 2003: Age-related susceptibility and resistance to Plasmodium berghei in mice and rats. Exp. Parasitol. 104: $81-85$.

Ramharter M., Winkler H., Kremsner P.G., Adegnika A.A., Willheim M., Winkler S. 2005: Age-dependency of Plasmodium falciparum-specific and non-specific $\mathrm{T}$ cell cytokine responses in individuals from a malaria-endemic area. Eur. Cytokine Netw. 16: 135-143.

Riley E.M., Allen S.J., Wheeler J.G., Blackman M.J., Bennett S., Takacs B., Schonfeld H.J., Holder A.A., Greenwood B.M. 1992: Naturally acquired cellular and humoral immune responses to the major merozoite surface antigen (PfMSP1) of Plasmodium falciparum are associated with reduced malaria morbidity. Parasite Immunol. 14: 321-337.

Riley E.M., Jakobsen P.H., Allen S.J., Wheeler J.G., Bennett S., Jepsen S., Greenwood B.M. 1991: Immune response to soluble exoantigens of Plasmodium falciparum may contribute to both pathogenesis and protection in clinical malaria: evidence from a longitudinal, prospective study of semi-immune African children. Eur. J. Immunol. 21: 1019-1025.

Seixas E., Ostler D. 2005: Plasmodium chabaudi chabaudi (AS): differential cellular responses to infection in resistant and susceptible mice. Exp. Parasitol. 110: 394-405.

Sher A., Pearce E., Kaye P. 2003: Shaping the immune response to parasites: role of dendritic cells. Curr. Opin. Immunol. 15: 421-429.

Shortman K., Liu Y.J. 2002: Mouse and human dendritic cell subtypes. Nat. Rev. Immunol. 2: 151-161.

Song X., Liang F., Liu N., Luo Y., Xue H., Yuan F., Tan L., Sun Y., XI C., XI Y. 2009: Construction and characterization of a novel DNA vaccine that is potent antigen-specific tolerizing therapy for experimental arthritis by increasing CD4+CD25+Treg cells and inducing Th1 to Th2 shift in both cells and cytokines. Vaccine 27: 690-700.

Su Z., Stevenson M.M. 2002: IL-12 is required for antibodymediated protective immunity against blood-stage Plasmodium chabaudi AS malaria infection in mice. J. Immunol. 168: $1348-1355$

TAYLOR-RoBinson A.W. 1995: Regulation of immunity to malaria: valuable lessons learned from murine models. Parasitol. Today 11: $334-342$.

TAYlor-Robinson A.W., Phillips R.S. 1994: B cells are required for the switch from Th1- to Th2-regulated immune responses to Plasmodium chabaudi chabaudi infection. Infect. Immun. 62: 2490-2498.

Taylor-Robinson A.W., Phillips R.S., Severn A., Moncada S., Liew F.Y. 1993: The role of TH1 and TH2 cells in a rodent malaria infection. Science 260: 1931-1934.

Troye-Blomberg M., Riley E.M., Kabilan L., Holmberg M., Perlmann H., Andersson U., Heusser C.H., Perlmann P. 1990: Production by activated human T cells of interleukin 4 but not interferon-gamma is associated with elevated levels of serum antibodies to activating malaria antigens. Proc. Natl. Acad. Sci. USA 87: 5484-5488.

Urban B.C., Ing R., Stevenson M.M. 2005: Early interactions between blood-stage plasmodium parasites and the immune system. Curr. Top. Microbiol. Immunol. 297: 25-70.

Vestergaard L.S., Lusingu J.P., Nielsen M.A., Mmbando B.P., Dodoo D., Akanmori B.D., Alifrangis M., Bygbjerg I.C., Lemnge M.M., Staalsoe T., Hviid L., Theander T.G. 2008: Differences in human antibody reactivity to Plasmodium falciparum variant surface antigens are dependent on age and malaria transmission intensity in northeastern Tanzania. Infect. Immun. 76: 2706-2714.

Walther M., Jeffries D., Finney O.C., Nuie M., Ebonyi A., Deininger S., Lawrence E., Ngwa-Amambua A., Jayasooriya S., Cheeseman I.H., Gomez-Escobar N., Okebe J., Conway D.J., Riley E.M. 2009: Distinct roles for FOXP3 and FOXP3 CD4 T cells in regulating cellular immunity to uncomplicated and severe Plasmodium falciparum malaria. PLoS Pathog. 5: e1000364.

Weiss W.R., Sedegah M., Berzofsky J.A., Hoffman S.L. 1993: The role of CD4+ T cells in immunity to malaria sporozoites. J. Immunol. 151: 2690-2698.

Wu J.J., Chen G., Liu J., Wang T., Zheng W., Cao Y.M. 2010: Natural regulatory $\mathrm{T}$ cells mediate the development of cerebral malaria by modifying the pro-inflammatory response. Parasitol. Int. 59: 232-241.

Wu Y., Wang Q.H., Zheng L., Feng H., Liu J., Ma S.H., CaO Y.M. 2007: Plasmodium yoelii: distinct CD4(+)CD25(+) regulatory $\mathrm{T}$ cell responses during the early stages of infection in susceptible and resistant mice. Exp. Parasitol. 115: 301-304.

Xainli J., Baisor M., Kastens W., Bockarie M., Adams J.H., King C.L. 2002: Age-dependent cellular immune responses to Plasmodium vivax Duffy binding protein in humans. J. Immunol. 169: 3200-3207.

Yanez D.M., Manning D.D., Cooley A.J., Weidanz W.P., van DER Heyde H.C. 1996: Participation of lymphocyte subpopulations in the pathogenesis of experimental murine cerebral malaria. J. Immunol. 157: 1620-1624.

Yazdani S.S., Mukherjee P., Chauhan V.S., Chitnis C.E. 2006: Immune responses to asexual blood-stages of malaria parasites. Curr. Mol. Med. 6: 187-203. 